\title{
On the footprints of a major Brazilian Amazon earthquake
}

\author{
ALBERTO V. VELOSO \\ Instituto de Geociências, Universidade de Brasília, 70910-900 Brasília, DF, Brasil \\ Manuscrito received on August 28, 2013; accepted for publication on December 10, 2013
}

\begin{abstract}
Combining historical accounts and seismological studies, three hundred years of dormant information emerged as a source of the largest known seismic event that rocked Brazil since the beginning of our colonization. The probable epicenter location of the 1690 tremor lies on the left bank of the Amazon River, about $45 \mathrm{~km}$ downstream from the modern day Manaus. A year later, while passing this area, a missionary met witnesses of the tremor and observed remarkable changes in the topography and vegetation along the margin of the river. By 1692 another priest confirmed this event and the occurrence of large waves in the river, which led to the flooding of the Native Indians' terrains. The tremor spread seismic waves throughout the forest and shook indigenous constructions as far as one thousand kilometers away. A calculation of the seismic parameters shows an estimated magnitude of 7, a maximum intensity of IX MM and a felt area of about 2 million $\mathrm{km}^{2}$. Due to the long recurrence period for this type of tremor, the discovery of one of these events is valuable for seismic global intraplate studies. As for Brazil, it unravels the myth that the country was never hit by severe earthquakes.
\end{abstract}

Key words: Amazon earthquake, historical tremor, intraplate seismicity, seismic intensity.

\section{INTRODUCTION}

The primary information of this unusual earthquake with epicenter in the state of Amazonas came from two Jesuit missionaries of the Society of Jesus, fathers Fritz (1880) and Betendorf (1909) who, at different times and independently, collected eyewitness accounts from people that felt and observed effects of the tremor that occurred in June 1690.

The geographer Sternberg $(1950,1953)$ was the first to reveal data on the severity of the earthquake: "If Father Fritz's chronicle is true the occurrence in 1690 would have been a real mega earthquake, a disastrous or catastrophic quake". Sternberg also provided a list of other Amazon tremors and although

E-mail: albertovveloso@gmail.com some of them are only long-distance effects of Andean earthquakes, his inventory is relevant because it proves that the Amazon region was not aseismic as many believed, including the Ballore (1906), organizer of the Seismological Service of Chile.

Three decades after Sternberg's (1950, 1953) publications, researches of the University of Brasília (Veloso and Mendiguren 1980) reviewed the information on historical Amazon earthquakes and added new instrumental data, including the one obtained by five seismographic stations, which had been installed by Eletronorte (Centrais Elétricas do Norte do Brasil) - in 1997 the Amazon region was upgraded with the first portable digital recorders and broadband sensors (Veloso 1997). They 
presented a new map of epicenters that reflect seismic activity similar to the rest of Brazil, but raised the question whether this level of seismicity was not a result of lack of seismographic stations in the past, since events of magnitude $\leq 5.0$ could not be detected by distant international stations. Despite being mentioned, the earthquake of 1690 did not receive further clarification other than those provided by Sternberg. Similar behavior occurred when making the first seismic-tectonic map of Brazil (Haberlehner 1978), or a general view of the Amazon seismicity (Veloso 1996). The book Sismicidade do Brasil also transcribed small excerpts from Fritz's diary and considered that the 1690 earthquake could have achieved large magnitude, but considered strange that the quake was felt as far as $1.800 \mathrm{~km}$ away without information of seismic effects on intermediate distances (Berrocal et al. 1984). Since there was mention of the occurrence of a hurricane and waves of great proportions, the authors of the book suggested that such phenomenon could have caused part of the damages observed in the epicentral area, however, the vibrations felt by the named Omaguas Indians far away, would have been produced by some Andean earthquake.

From the foregoing, there is the impression that the geoscientists agreed on the authenticity of the earthquake of 1690, but questioned its location, its size and its felt distance. Strangely, historical information was never reassessed and the stated uncertainties continued unanswered. Thus, the event of 1690 appears in the Brazilian seismic archives discreetly: incomplete date, location at the mouth of the Negro River and "hurricane effects", as a possible cause. With this "official mark" it has gone through time and when it appears is does so in the form of a meaningless point in Brazilian seismic maps. Perhaps the great distance indicated for the perception of the earthquake, lack of additional information and other misinterpretation contributed to the disinterest over this historical event.
However, this paper does not assign the occurrence of any important Andean earthquake in June of 1690. Catalogues of South American earthquakes indicated only two important events for the year of 1690; one in Chile and another in Peru (CERESIS 1991). For the first tremor, the only information available was the date - July 9 and an estimate of the epicentral coordinates: $33^{\circ}$ $4 \mathrm{~S} ; 70^{\circ} 6 \mathrm{~W}$, which indicated that the location was in Chilean territory. This earthquake was felt in Santiago with VIII MM and caused one death and minor damages (E. Kausel, pers. comm). Even with this large intensity, it was not among the Chilean earthquakes with a magnitude $\geq 7.0$ (Servicio Sismologico U.C. 2010). Regarding the Peruvian earthquake it occurred on November 20 and the shock finished ruining buildings and churches in the capital that were still standing after surviving a previous earthquake in 1687 (Domingo 1940).

With such information, it is evident that neither of these two Andean earthquakes were the cause for the damages that occurred in Brazilian territory as a result of the 1690 event. Thus, it appears inappropriate to explain the historical earthquake through two distinct and simultaneous occurrences, one which took place at the mouth of the Negro River and the other in the land of the Omaguas Indian. We favor the earthquake of June 1690 was a purely Brazilian event that produced effects in parts of the Brazilian and Peruvian Amazon terrains.

We believe this paper offers new insights into the almost forgotten June 1690 earthquake and brings back this impressive event to the Brazilian scenario of earthquakes.

\section{HISTORICAL SETTING}

A more detailed account of the tremor was provided by Samuel Fritz who spent almost 40 years of his life converting the Indian tribes of the Upper Amazon, among them, we highlight the Omaguas, a powerful nation whose lands, at the 
banks of rivers and islands, extend about $800 \mathrm{~km}$ from the proximity of the Napo River in Peru to the mouth of Jurua in Brazil ("L1 to L2"in Fig. 1A). At least two of his legacies have relevant scientific implications, a geographical map and a diary. In 1691 he concluded a chart depicting the course of the "Maranõn-Amazonas" and its main tributaries, from the Peruvian coast to the Atlantic Ocean, including the location of towns, Indian villages and pathways over a broad isolated area (The Fritz's map of 1691), (Fig. 1A).

Coincidently, a copy of this map was used and enhanced 26 years later, by the geophysicist La Condamine (2010), who after working in Ecuador with Pierre Bouguer to measure the degree of the meridian arc near the equator, decided to return to Europe, via the Amazon River. On this trip La Condamine conducted geodetic measurements and improved the original map, particularly in the area of the lower Amazon. He also collected information of flora and fauna, one of the first scientific narratives about the region. Fritz's map had inaccuracies because the priest did not have a pendulum nor a telescope to determine longitudes and used "only a wooden semi-circle of 3 inches in radius, for latitudes," says La Condamine.

Fritz also wrote a diary that was only published after almost two centuries in Spain, by La Espada (1889). Part of these writings came to Brazil in two ways. The first was when Pedro II, Emperor of Brazil, ordered the transcript of various documents related to the Brazilian history from the library of Evora, Portugal (Fritz 1880).

Later, the Brazilian historian Garcia (1912) rediscovered the diary in Evora and translated it into Portuguese, adding valuable notes. There is an English version of the diary from Edmundson (1922), from the Hakluyt Society in London, another from the Ecuadorian historian Rodrigues (1997) and recently a new edition was organized by Professor Pinto (2006), from the Federal University of Amazonas.
Part of Fritz's Diary has special value to Brazilian seismology, as follows. On September 4, 1691, about fifteen months after the earthquake, Fritz met with another missionary, Father Theodosio Vegas, $10 \mathrm{~km}$ below the mouth of Urubu River (\# 1 in Fig. 1B) and learned about "an earthquake and horrible parting asunder of the ground, which had occurred some eight leagues higher up, on the same northern shore" (Edmundson 1922). Two days later, he wrote in his diary again "on the 6th in the morning on the north bank we came upon the lands, where in the month of June of the past year, 1690, there was a very great earthquake; ruins of large villages were visible, fallen rocks, huge plantations uprooted and thrown into the river, very high ground with the scrub on the top fallen, and white, red and yellow earth, stones and trees hurled from the height and piled up above the river. In another part lagoons drained, woods destroyed and everything mixed together in disorder. Where the soil had been of sand and clay, there had not been any havoc. Fr. Theodosio said that at the same time there were terrible tides in the river and an immense quantity of fish died, and this the natives were attributing to my detention, saying that Para and all of them were doomed to perish. They were declaring further that for some four leagues (about $20 \mathrm{~km}$ ) of the river there had been even greater havoc inland, and that the earthquake had traveled for some three hundred leagues upstream as far as the islands of the Omaguas, whose houses, they told me afterwards, had been much shaken" (Edmundson 1922). The Father also noted that on the mouth of the Negro River (\# 3 in Fig. 1B) more than eighty Taromas Indians came to see him with several gifts, but "all were much afraid of me because of the earthquake referred to".

Samuel Fritz was educated and resourceful. Also a good draftsman, he was skilled in estimating distances and he had an accurate sense of orientation and geographical and topographic knowledge. He taught the natives agricultural skills, built churches 


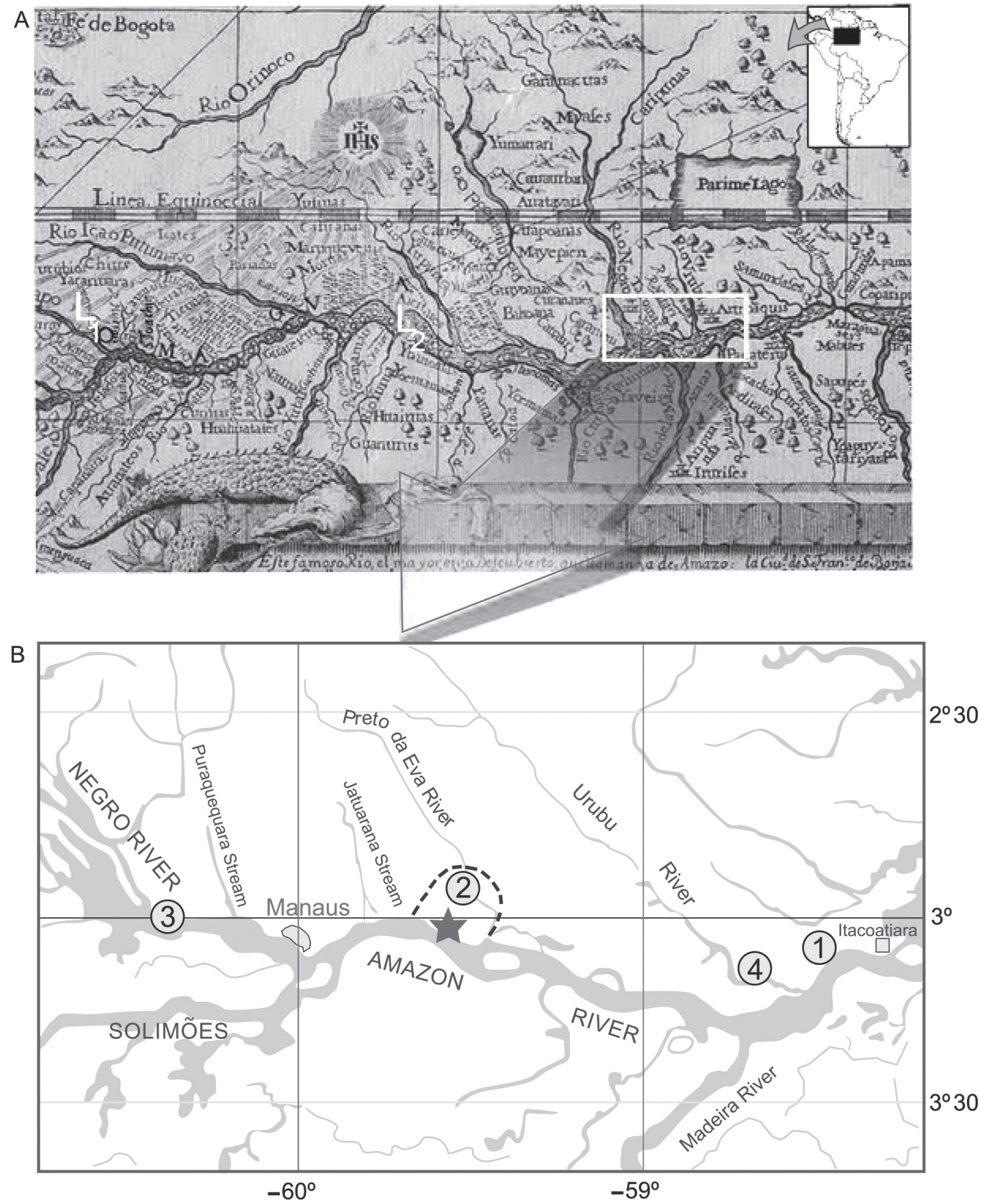

Fig. 1 - Ancient and modern maps of portions of the Amazon region. A, Section of Fritz's Map of 1691 and engraved at Quito in 1707. L1 and L2 make the limits of the Omaguas lands from the mouth of Napo River, close to the mission of San Joaquin, in Peru, until the mouth of Jurua River, in Brazil. B, Part of an Amazonas State map indicating key sites: 1, where Fritz learned about the tremor for the first time; $\mathbf{2}$, estimated epicenter of the 1690 event and the most affected area - dashed line; $\mathbf{3}$, location of the Taromas' Village whose residents felt the tremor; 4, the Indian Village on the bank of the Urubu River which overflowed according to father Betendorf. 
and some of their numerous missions became cities like Tefe, Fonte Boa, Coari and São Paulo de Olivença (Reis 1989). The missionary was an outstanding observer of nature and its surroundings. Fritz accurately identified and reported, without hype, the damage caused by floods, or distinct phenomenon such as the fallen lands, or the different colors of the waters on the confluence of the Amazon and Negro rivers. Traveling through the seismic terrains of Peru and Ecuador, he knew about earthquakes and their effects.

It is important to say that Samuel Fritz belonged to the Spanish branch of the Society of Jesus and tried to enforce the Tordesillas Treaty - agreement between Spain and Portugal aimed at settling conflicts over lands newly discovered outside Europe - which led to several disputes with the Portuguese, whether they were missionaries, military or Indian hunters. Once, while staying near the mouth of the Negro River, Fritz was stricken with serious illness and decided to seek help in the City of Grão Pará (Belém). After he was healed, he was imprisoned on charges of espionage. Almost two years later, he was released and sent back to his main mission located in the San Joaquin of the Omaguas, present day Pebas, in Peru (Fig. 1A). Therefore, it was thanks to that return trip that Fritz learned about the 1690 event.

Additional information on the earthquake was provided by Joao Fellipe Betendorf, appointed by Rome to serve in the Captaincy of Maranhão, which also encompassed the land of Grão Pará. The 33 years old missionary gained a good chunk of the Amazon to act on. Betendorf held several administrative positions while converting the Native Indians and adapted himself to the point of preaching sermons in the Tupi language. One of his major contributions was the reporting of the major historical, political and religious events that occurred within the captaincies (Betendorf 1909). Because Betendorf described such events with great details and seriousness, his body of work became a great source of historical facts, including seismology, due to his narration of a fact that validates and expands the descriptions made by Samuel Fritz about the earthquake of 1690.

In one of his explorations in the Amazon, Betendorf met with Father Theodosio Vega, who was in charge of missions in the area of the Urubu River since 1668 (Reis 1999). In his conversation with the missionary and other Native Indians, Betendorf realized that the earthquake from two years earlier still caused terror to all. "A few months ago there was a terrible earthquake around that area, and Father Theodosio told me that as he was walking in the Amazon River, all of a sudden the water started moving, thickening and agitated in such manner that he was able to stay alive by taking shelter on a small island. Some Native Indians from the Urubu River said that the river had overflowed to the point that it submersed a village, but I believed it was not true; it was true that there had been a great flood, however, from all the ones which had been said to be submerged, none of them really were, because I found them in their place and later I walked through all of them on my own two feet", Betendorf wrote.

Considering that Fritz and Betendorf visited the scene one and two years after the earthquake, and that both missionaries had good understanding with Father Theodosio - an eyewitness of the tremor - and none of them had any problems with the languages spoken by the Indians, we believe that the chances of having misunderstood the details of the seismic event were very small. Therefore, the historical accounts provided by the two missionaries were the basic material to develop all investigation related to the 1690 earthquake.

\section{EFFECTS OF THE 1690 EARTHQUAKE}

The powerful and prolonged tremor produced ground failure near the epicentral area, the trembling was felt across long distances and the shock caused atypical effects on the waters of the Amazon and Urubu rivers. 
Fritz wrote that "the earthquake had travelled for some three hundred leagues up stream ...", therefore it is important to clarify the meaning of that distance, since it could be the limit to the perception of the tremor. The unit of distance used by Fritz was the Castilian League, equivalent to $5.257 \mathrm{~m}$ (Garcia 1912). In other words, 300 leagues would be 1.600 $\mathrm{km}$, approximately. If we use the graphic scale from Fritz's map and consider the starting point close to the mouth of the Urubu River (\# 1 in Fig. 1B), where he heard about the earthquake for the first time, the distance to San Joaquin ("L1" in Fig. 1A) is 250 leagues, but if one follows the river, it would be 290 leagues, a number very close to what was described by the priest. Therefore, choosing the village of San Joaquin as the limit distance of where the tremor was felt seems like a better option to explain the " 300 leagues", even more so when we consider that it was in Omaguas lands that the houses shook. According to our understanding, this macroseismic effect marks the outer limit of perceptibility for intensity IVMM. Naturally, Fritz's map has inaccuracies, such as the Negro River flowing from the north and not from the northwest, but the relative precision of some locations is notable. Such is the case of San Joaquin and Belém cities, which are at the same distance from the epicenter, but opposite each other. In today' $\mathrm{s}$ maps that distance is of $1.300 \mathrm{~km}$, approximately.

Along more than $20 \mathrm{~km}$ (\# 2 in Fig. 1B) Samuel Fritz observed a large amount of superficial damage, upturned soil mixed with stones, large cracks and open fissures, drained lagoons and newly created ones, destroyed groves and large trees uprooted and dropped into the river. He also reported that the change in landscape was not restricted to portions of the river banks, because damage could also be found inland which could represent a liquefaction area greater than $300 \mathrm{~km}^{2}$. In order for that to occur, the saturated bottomland of the river valley must have been shaken very intensely inducing a liquefaction process. Thus, areas of saturated sandy layers lost resistance entirely, and because of such fluidity stretches of land slid, others areas sunk, or even raised.

These land movements are features commonly associated with soil liquefaction and have been observed in other historic earthquakes, such as the New Madrid, 1811, 1812 tremors with estimated magnitudes about 7.3 (Nuttli 1973). This quake made previously rich prairie land unfit for farming because the ground was covered by swamps, sand, mud and deep fissures. Similar effects had been noted in the 1886 Charleston intraplate earthquake, with estimated magnitude of 7.1 (Stover and Coffman 1993). In the epicentral area more than $1.300 \mathrm{~km}^{2}$ of cratering and fissuring were widespread and a series of wide cracks opened parallel to the Ashley River. Several large trees were also uprooted when the bank slid into the river. During the great Fort Tejon earthquake of January 9, 1857 M7.9, on the San Andreas Fault, trees were uprooted about $20 \mathrm{~km}$ from the epicenter (Stover and Coffman 1993). Recently, the moderate $6.3 \mathrm{New}$ Zealand earthquake, on February 22, 2011, produced dramatic effects of liquefaction at Christchurch, including uprooted trees (Otago Daily Times 2011), which had also been observed in the M6.7 Turkey quake, July 10, 1894 (Ince 2011) and in the Philippines M6.6 tremor of February 5, 1970 where coconut trees were uprooted (EIB 1970). Another remarkable liquefaction process was triggered by the September 24, 2013 M7.7 earthquake that rattled the south-central part of Pakistan. The earthquake caused the seabed to rise and created a small, mountain-like island, made of a mixture of mud, fine sand and solid rock, near the town of Gwandar, about $400 \mathrm{~km}$ from the epicenter. The same region produced similar islands in the past, known as mud volcanoes (Deslile 2004), but all of them were washed away within a few weeks, or months.

According to Fritz the 1690 earthquake made noise and the water in the rivers shook strongly, hence the statement of the witnesses of a horrible swell with death of fish. The intense vibration of the terrain must have agitated a large volume of 
water and some of them may have spewed from the riverbed, dragging many fishes - if extensive, this effect indicates intensity XMM, according to Richter (1958).

The information provided by Betendorf confirms the unusual behavior of the Amazon River and also that there was an overflow of the Urubu River. It is possible that the disturbance in the Amazon River generated large waves that beat against the banks causing some of its water mass to penetrate the mouth of the Urubu River pushing water in the opposite direction of the flow, so as to produce a flood in Indian villages. Flooding may have been significant it occurred during the rainy season, and as the water level rose even higher, the waters affected one or another village ordinarily not reachable by the water. Although Betendorf found that no "village was overturned", i.e., it was not completely destroyed, it is possible that Indian homes suffered some damage. Fritz's map indicates these villages as being 5 to $15 \mathrm{~km}$ upstream from the Urubu mouth (\# 4 in Fig. 2A). It is important to state that the above mentioned New Madrid earthquakes of 1811-1812 also produced impressive effects along rivers, particularly on the Mississippi. Eyewitness accounts of the quake said that islands disappeared; fissures opened and closed in the river beds, the ground suddenly raised to form new water-falls that survived for days. The current of the Mississippi was driven back upon its source as a consequence of the elevation of the riverbed due to the vertical movement of the fault that crosses the river, disrupting its natural flow.

Earthquakes can move enclosed bodies of water such as bays and lakes, back and forth allowing the formation of stand waves named seiche. Since the Amazon River is quite wide it could act as a lake, facilitating the appearance of seiches. However, this seems not to be the case for the 1690 tremor, since the water did not splash over the banks as a river-seiche. Undoubtedly, the force of the running waters that entered the mouth of the
Urubu was strong enough to reverse the river flow and this effect, according to our understanding, more resembles the action of tsunami-like waves, or the so-called pluvial tsunami, than a simple oscillatory motion. Such secondary effect of this historical quake is remarkable because it validates an event that was not only rare, but also occurred in an unexpected location. Thus, instead of identifying a tsunami in coastal regions where they usually happen, there is suggestion that this phenomenon occurred, albeit in a reduced scale, in the core of the Brazilian Amazon Forest. There may not be real data to explain this unusual water movement but it may happened in the same way as in the Mississippi, i.e., by a sudden vertical displacement of the Amazon riverbed.

Historical accounts do not provide everything we would like to know. For example, there is no information regarding aftershocks of the 1690 tremor. Did they occur? Absence of aftershocks should be the exception rather than the rule for major tremors. Usually the main quake is followed by dozens of noticeable shocks and it is most probable that they happened in 1690. A possible explanation for this lack of evidence is incompleteness of past records.

One cannot say that Manaus was affected by the earthquake because the city barely existed at that time. Manaus grew slowly around a fortress and Fritz marked its location in his map. Historian Monteiro (1994) wrote that in 1669, "a fort like structure was raised made of stone and mud, with a square shape, but without a ditch, in the left riverbank of the Negro River". With four pieces of artillery and a garrison the size of ten blocks, it was named as "Forte de São José da Barra do Rio Negro", since it was three leagues from the intersection of that river and Solimões. The same author says that in 1689, Father João Maria Gorzoni started to attract the "Indians to the fort's surroundings". In 1695 the Carmelite Fathers built, next to the fort, a small thatched chapel with the name "Nossa Senhora da Conceição". Therefore, 
at the time of the 1690 earthquake, Manaus was just a small village, reaching a resident count of 34 whites, 220 Indians and two black slaves in 1778 (Monteiro 1994).

\section{SEISMOTECTONIC IMPLICATIONS}

Brazil, within the South American Plate, comprises one of the most stable regions in the world and its mid-plate earthquakes has never exceed magnitude 6.2 and intensity of VIIMM. Geological processes that move faults and cause earthquakes in Brazil arise from a complex interaction of neotectonic forces, predominantly horizontal compressive stresses. They come from a Mid-Atlantic ridgepush, asthenosphere drag resistance, the resistive forces exerted by the Caribbean Plate to the north, combined with the Nazca-South American Plate convergence to the west. Where should we expect seismic activity as the result of these geological forces? The continents retain part of their histories in geologic features such as failed rifts, sedimentary basins, plutonic intrusions and intersecting faults that end up becoming crustal weakness zones. When there is a build-up of tectonic stress in the vicinity of such geological structures, they can be reactivated and that is the cause of the majority of the intraplate earthquakes, like the ones that struck Brazil. Interestingly, $64 \%$ of the global stable continental region seismicity is associated with extensional basins or grabens (Johnston et al. 1996, Schulte and Mooney 2005). In other words, failed rifts represent the most important pre-existing zone of crustal weakness for intraplate seismicity as revealed from a global compilation (Gangopadhyay and Talwani 2003).

There are no known elements to correlate any major fault with the tremor of 1690 , but there are important regional structures that could have facilitated the occurrence of the historical quake. One of the great marks of crustal weakness is the Brazilian shield rifting, with posterior Paleozoic sedimentation of the "Acre, Solimões, Amazonas and Marajó" basins (Loczy 1970). Of all of them, the most important one for the present study is the Middle Amazon Basin, more precisely its western part next to the Purus Arch, a structural high, roughly N-S trending, that separates the Middle and Upper Amazon basins.

The Amazon Basin shows strong positive gravity anomalies roughly aligned E-W, coincident with its major axis of deposition (Linser 1974). These succession of gravity highs ( +40 to $+90 \mathrm{mGals}$ ), flanked by lows of gravity (- $40 \mathrm{mGals}$ ), following approximately the axis of greatest average thickness of the Amazon Basin, can be explained "by a steeply sided zone of high density in the lower crust varying in width from 100 to $200 \mathrm{~km}$ wide" (Nunn and Aires 1988). This huge intrusion from the mantle causes flexural stresses that substantially modify the regional E-W compressive stress direction present in the South American Plate (Zoback and Richardson 1996). The same concept was applied to the stress associated with the high density rift pillow beneath the New Madrid Seismic Zone (NMSZ), in the United States, where the concentration of local force rotated the direction of the resulting maximum horizontal compression, from $10^{\circ}$ to $30^{\circ}$, (Grana and Richardson 1996).

The proposed 1690 earthquake occurred in one of the Amazon seismic zones, near the two largest intraplate earthquakes recorded in the state of Amazonas: M5.1 on December 14, 1963 and M5.5 on August 8, 1983, as shown in Fig. 2, which also illustrates the seismicity and geology of part of the Amazon region. Both tremors had atypical focus depth of $45 \mathrm{~km}$ and $23 \mathrm{~km}$, respectively (Assumpção and Suárez 1988).

Quite apart from the rest of Brazil, where the vast majority of earthquakes have shallow depths of $\leq 15 \mathrm{~km}$, the Amazon earthquakes of 1963 and 1983 were deeper events of stable continental regions under a compressional regime. Their spatial location suggests a causal association with the zone of the densified lower crust pointed out by high gravity anomalies (Fig. 2). 


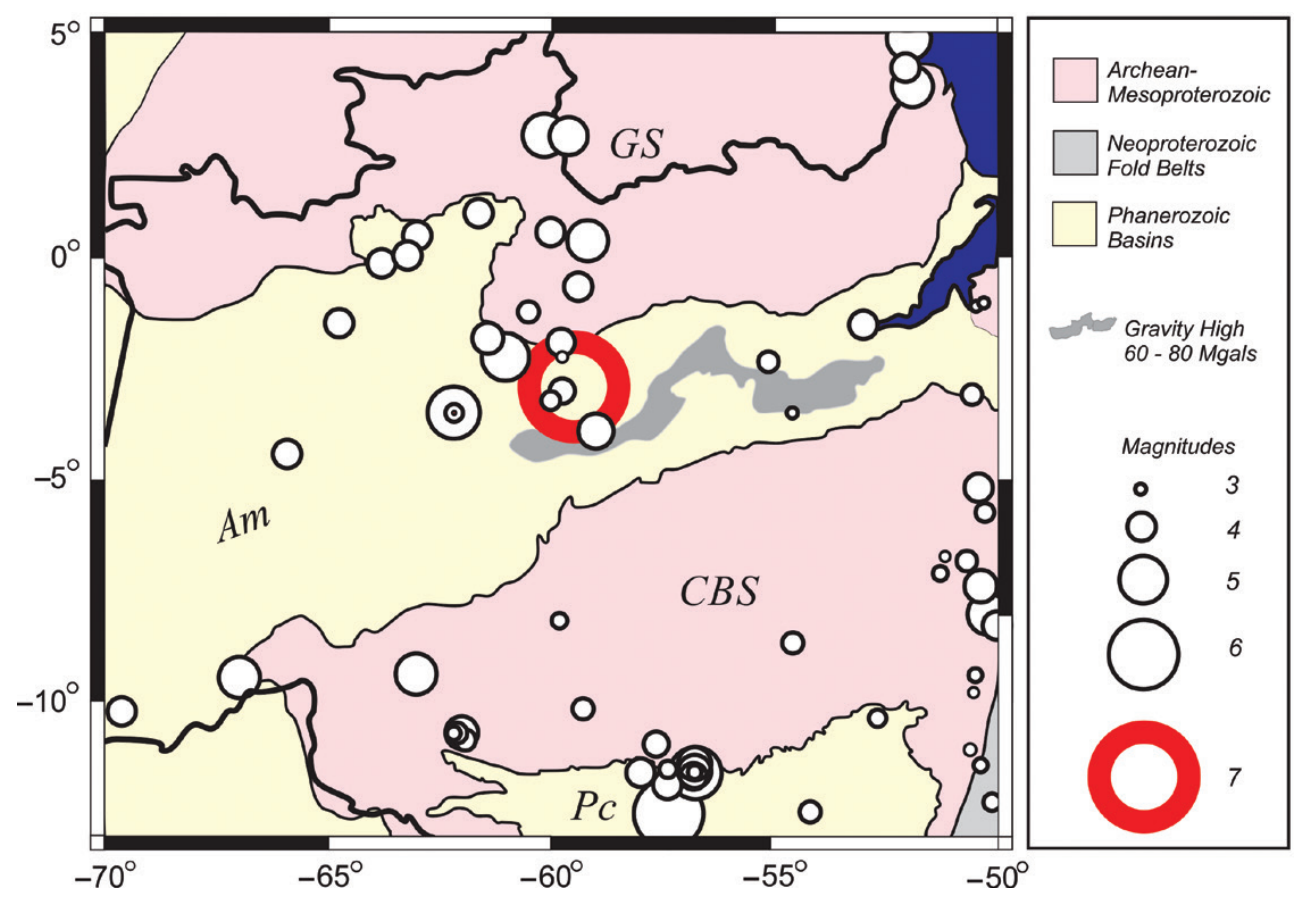

Fig. 2 - Seismicity, geology and gravity anomalies of part of the Amazon region. Epicenters (white circles, from the Brazilian Catalog) have magnitude $\geq 3$.0. Large ring is the 1690 earthquake. Solid line is the boundary between the Amazon Basin (Am) and the Guiana (GS) and Guapore (CBS) shields. $\mathrm{Pc}$ is the intracratonic Parecis Basin. The continuous grey shape marks the E-W trend of high gravity, from Sa 2004.

The epicenter location of the August 8, 1983 (Assumpção et al. 1983) tremor lies outside of the area covered by the gravity high, but it is possible that its hypocenter was in the periphery of the long and wide intrusive body that extended to the west direction, as inferred by Nunn and Aires 1988. Flexural effects from crustal loads can reach a few hundred kilometers, as modelled by Zoback and Richardson (1996). The focus of the December 14, 1963 tremor lies in the mantle (Assumpção and Suárez 1988), beneath a crustal thickness of about $42 \mathrm{~km}$ of the Amazon Craton, defined by tomography studies (Feng et al. 2007). Fig. 3 displays the tridimensional geometry of the high density material in the crust and also shows the positions of the three nearby large earthquakes.

The focal mechanism of the 1963 and 1983 Amazon quakes indicated a predominantly thrust fault with aboutNNW-SSE and NNE-SSW horizontal compressive axis, respectively (Assumpção and
Suárez 1988). Nevertheless, another investigation suggested that Amazon Rift may be a contributing factor to modify the current regional stress - E-W to NW-SE - "causing a roughly $90^{\circ}$ rotation of the horizontal stresses" (Grana and Richardson 1996). Therein the load of the enormous mafic intrusion present in the lower crust would generate a local stress field almost perpendicular to the main axis of the Amazon Basin (Fig. 3). This flexural deformation could be a major factor to explain the Amazon regional seismicity as proposed by Assumpção and Sacek (2013) for the intraplate seismicity in central Brazil. The current set of tectonic stress present in that part of Brazil should be similar to the one from 300 years ago. Thus, the relative geographic proximity between the 1690 earthquake and the tremors of 1963 and 1983 suggests the same thrust fault mechanism for all of them - pending further investigations, this seems plausible albeit speculative. 


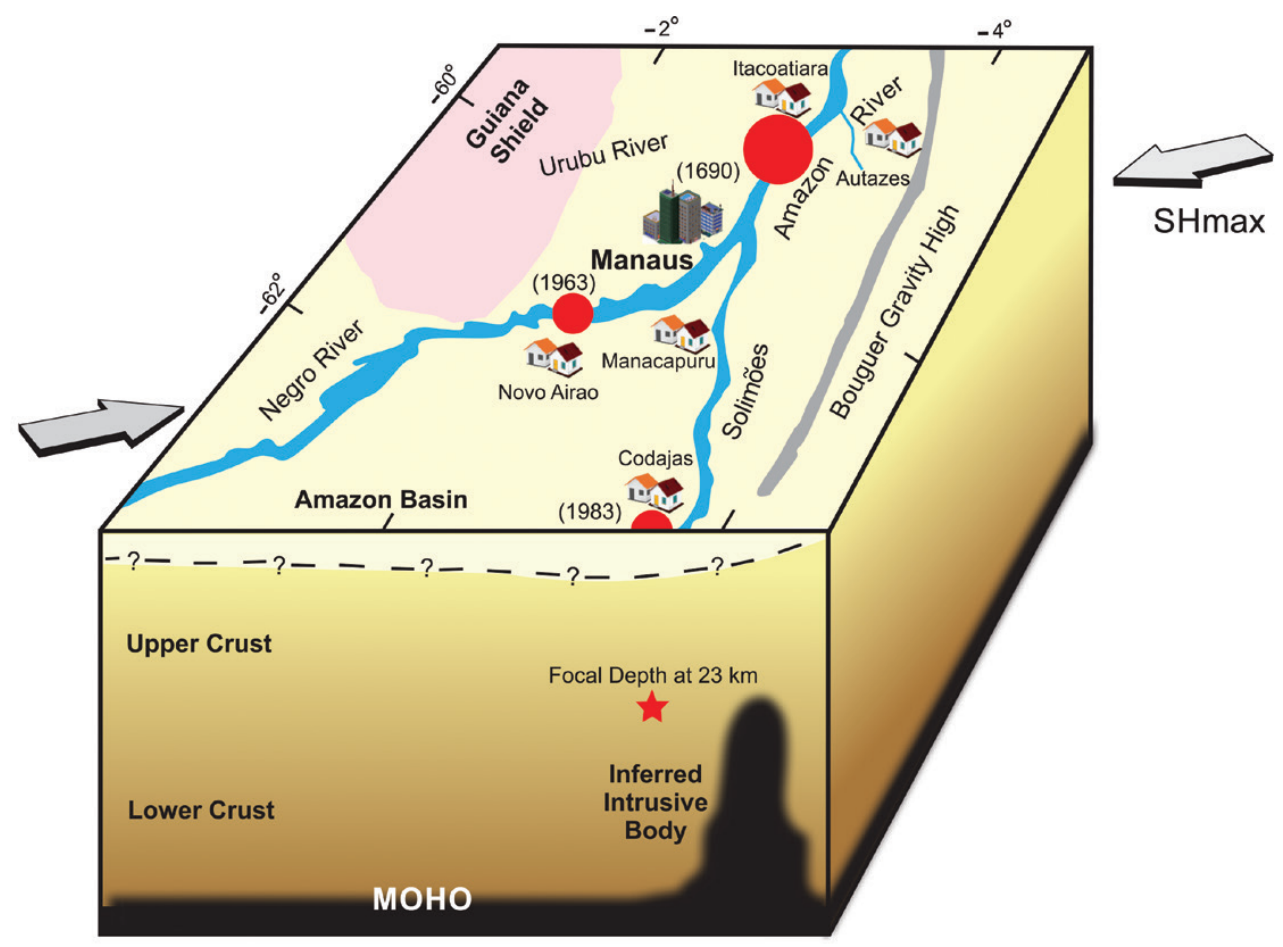

Fig. 3 - Block diagram illustrating the inferred configuration of the crustal section around the three main Amazon intraplate earthquakes. The pink area is the exposed Guiana Shield and the yellow area is the Amazon Basin. The black solid line is the E-W trend of high gravity and the red circles are the three main shocks. Manaus and other small cities are represented. External arrows are estimates of the maximum horizontal stress direction (SHmax) from reverse fault mechanisms of the 1963 and 1983 earthquakes. Depths of Amazon Basin, upper and lower crust, the mantle topography and the intrusive body are inferred from Nunn and Aires, 1988. The star indicates the focal depth at $23 \mathrm{~km}$ of the 1983 tremor.

\section{QUANTIFYING THE 1690 EARTHQUAKE}

The left riverbank of the Amazon where Fritz noticed ground failure, between the Jatuarana tributary and the Preto da Eva River, is considered the epicentral area of the earthquake ("star" in Fig. 1B). Maybe this is incorrect, since the tremor could have caused similar changes in other parts of the terrain, but for lack of better option this spot becomes the probable epicenter.

Based on the reported descriptions of soil effects - conspicuous cracks in ground, earth slump, slides of steep slopes, soil masses displaced, water thrown on banks of river - the maximum epicenter intensity of the 1690 tremor was conservatively estimated in IXMM, according to the Modified Mercalli Scale 1956 version (Richter 1958). The Indian villages located on small islands and on the shores of the main drainages facilitated the perception of the tremor, since in those unconsolidated terrains the seismic waves tend to be amplified and its effects become more evident.

Fritz considered that the quake was felt for 300 leagues and he possibly arrived at such conclusion when he estimated the distance measured along the river, between the mouth of the Urubu River where he heard of the earthquake for the first time - until San Joaquin, $\pm 1.300 \mathrm{~km}$ away. However, there is no clear indication that it was in San Joaquin that the houses trembled, although this spot fits very well with the 300 leagues mentioned by Fritz. To compensate for this uncertainty, a conservative assumption was made considering 
$1.000 \mathrm{~km}$ as the maximum distance that the quake was felt (i.e. Mercalli Intensity IV), to the west. Such value roughly corresponds to the distance between the central portion of the Omaguas land to the estimated epicenter. No information was found that the tremor was felt in Belém, located to the east about $1.300 \mathrm{~km}$ of the epicenter.

Therefore, towards the east, the limit of the distance where the earthquake was felt was also reduced to $1.000 \mathrm{~km}$, arbitrarily.

The area where the tremor was felt encompassed by the IVMM intensity was represented by an elongated ellipse, with its major axis closely matching with the main axis of the Amazon Basin (Fig. 4), which also presents the approximate felt area of the 1955 earthquake, the largest ever recorded in Brazil, of with the field investigation to obtain seismic intensity data was conducted 31 years later (Assumpção and Veloso 1987). Starting at the point believed to be the epicenter, there is no data east of the Urubu River. Towards the west, there are two pieces of information: the Taromas Villages, about $50 \mathrm{~km}$ from the mouth of the Negro River, where the Indians also felt the tremor (\# 3 in Fig. 1B) and possibly the mission of San Joaquin, already in Peru (close to "L1" in Fig. 1A). Note that the villages where Fritz passed "were burnt and deserted; the people having fled to the forest due to fear of the Portuguese slave-raiders", Edmundson (1922). Therefore, the missionary travelled through a broad area without meeting people who could provide him with information of the earthquake.

Since in the North-South directions there is no mention of the effects of the tremor, a macroseismic map of the 1983 Codajas earthquake was used as reference to drawing the shape of the felt area for the historic event. From the 1983 isoseismal map the relationship of 1.5 was found between the major and minor axes of the four ellipses for intensities ranging from II to VMM. A felt area of two million square kilometers was defined with this factor taking 1.000 $\mathrm{km}$ and $650 \mathrm{~km}$ as the dimensions of the semi-major and semi-minor axes, respectively (Fig. 4).
To determine the most likely magnitude of the 1690 tremor two equations based on intensity of shaking have been chosen among several other empirical relations. The first relates the felt areas to the magnitude of historical earthquakes, such as the ones used in the seismic studies in eastern United States that can also be applied to other intraplate regions, as Brazil (Johnston 1996). It is calculated using the following formula

$\log (\mathrm{Mo})=18.53+0.823 \log \left(\mathrm{A}_{\mathrm{IV}}\right)+0.00188\left(\mathrm{~A}_{\mathrm{IV}}\right)^{1 / 2}$

where Mo is the seismic moment and $\mathrm{A}$ is the felt area for IVMM. The moment magnitude $\left(\mathrm{M}_{\mathrm{w}}\right)$ is calculated from the seismic moment using the relation below

$$
\mathrm{M}_{\mathrm{w}}=(\log \mathrm{Mo} / 1.5)-10.73
$$

The other relation (Bakun et al. 2003) is fit median $\Delta$ for MMI levels, where we obtain the following intensity-distance relation

$\mathrm{MMI}=1.41+1.68 \times \mathrm{M}_{\mathrm{w}}-0.00345 \mathrm{x} \Delta-2.08 \log (\Delta)$

where $\mathrm{M}_{\mathrm{w}}$ is moment magnitude and $\Delta$ is epicentral distance $(\mathrm{km})$

As a result, the estimated magnitude of the 1690 tremor from both equations, expressed in moment magnitude, was 6.9.

Obviously, this is an approximate magnitude that gives an idea of the size of the quake and since the goal is to set a final number for the 1690 event, $\mathrm{M}_{\mathrm{w}} \approx 7$ became the preferred value. Based on Brazilian earthquake history, a large earthquake such as the 1690 would occur somewhere in the country on average once every 500 years (Assumpção 2011).

What is important is to highlight the effects of the tremor on the ground and to imagine what would happen if it occurred today. Therefore, many buildings and other important infrastructure constructions located on the typical unconsolidated sediments of the Amazon region make them far more susceptible to earthquake damage, Fig 4. 


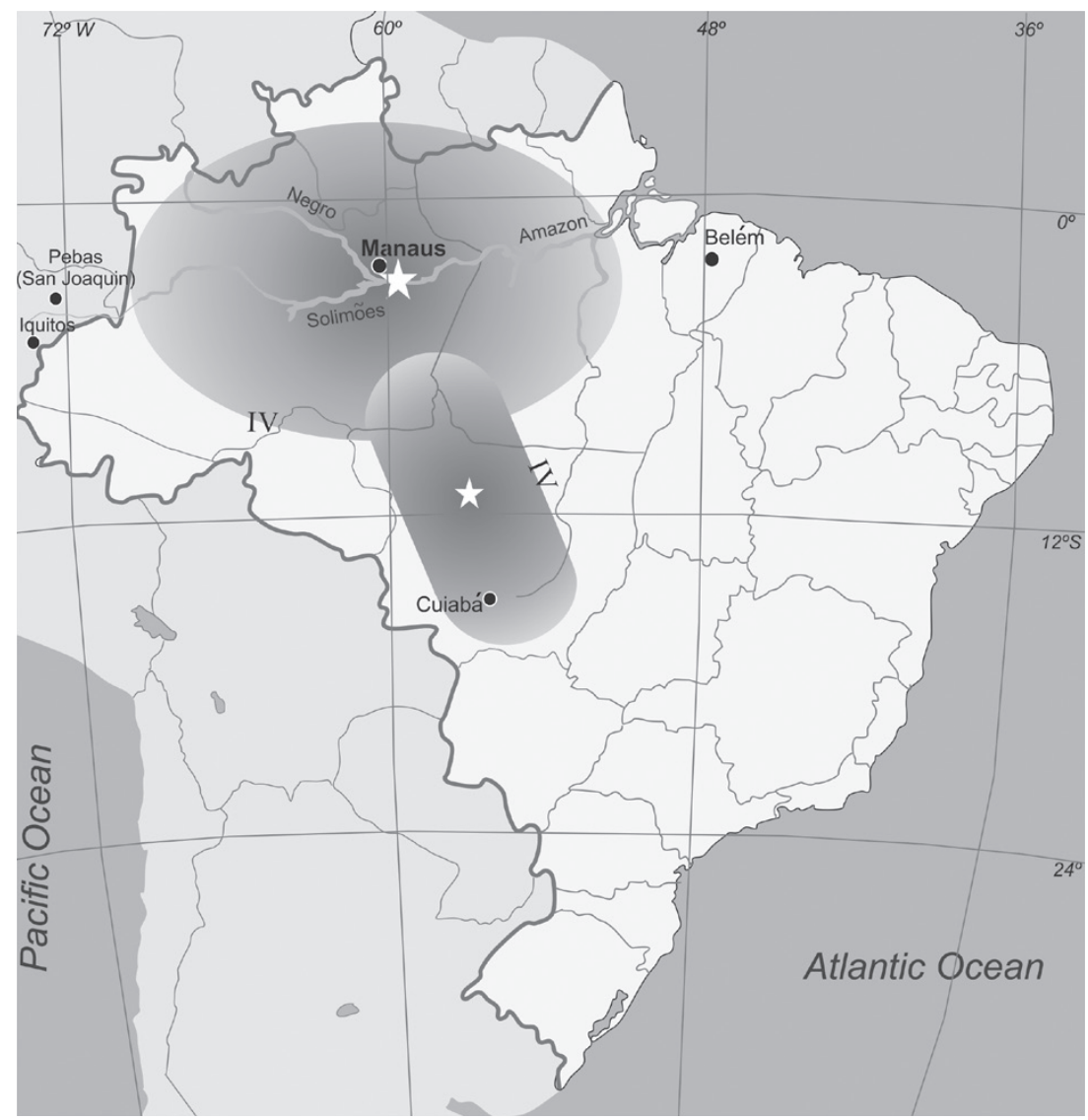

Fig. 4 - Comparison between estimated felt areas of the 1690 earthquake and the January 31, 1955 tremor, the largest ever recorded in Brazil (6.2 mb). Two shaded shapes represent the best fit ellipses for intensities IVMM centered at estimated epicenters. Data do not exist to indicate intensities to the north of 1955 epicenter and as result that isoseismal line was inferred. The estimated felt area of the 1690 and 1955 earthquakes are about 2 million square kilometers and 600.000 square kilometers, respectively.

From now on, regional seismic hazard studies need to take the current findings into account.

\section{CONCLUSIONS}

The historical tremor shook and deformed the ground, which also suffered liquefaction, the rivers were violently shaken and trembling was felt at long distances. No one has ever heard of anything similar happening in other parts of the country, and for now, it earns the rank of the largest earthquake known in Brazil. Below are the most significant results of this study.

- The probable epicenter location of the 1690 tremor is on the left bank of the Amazon, between the Jatuarana tributary and the Preto da Eva River, about $45 \mathrm{~km}$ downstream from the modern day Manaus; a city with almost 1.9 million inhabitants;

- at the epicenter the intensity could have reached IXMM and the tremor probably produced liquefaction in an area greater than $300 \mathrm{~km}^{2}$ (\# 2 in Fig. 1B). To the west of the historical epicenter seismic intensities of IVMM were probably felt up to $1.000 \mathrm{~km}$ away;

- an earthquake of similar strength in the future could have tragic results for near and far away nowpopulated urban areas, where the seismic waves would be amplified in the terrain of the Amazon sedimentary basin. This scenario implies that 
seismic hazard in this region is more significant than indicated by previous studies;

- the preferred magnitude value to represent the 1690 earthquake is $\mathrm{Mw} \approx 7$. For Brazil this size of tremor would have a return period of about 500 years and this is consistent with the news of only one event in the last three centuries;

- the estimated magnitude of 1690 tremor released seismic energy greater than the sum of all earthquakes registered in Brazil until now. Even if such value of the magnitude is exaggerated, it would have to be reduced by about one unit of its original value in order for it not to be considered the strongest quake in the country;

- historical accounts indicate that during the earthquake abnormal waves appeared in the Amazon River flooding native villages on the banks of the Urubu River. Such phenomenon could be interpreted as being similar to the effect of small tsunami-like waves in the core of the Amazon jungle;

- although less significant than the series of historical earthquakes of 1811-1812 in the Mississippi Valley, Midwest of United States, the Brazilian earthquake of 1690 is not without similarities with its American counterpart. They are alike because they occurred on rift-basins within stable continental regions and also featured huge felt area and produced significant ground deformations;

- it is expected that the historical Brazilian earthquake will stimulate new field investigations, not only to prove its occurrence, but also to discover possible paleoseismic records in the Amazon region. This type of data would be of great value to benefit the poorly known seismic history of the region.

Analysis of historical accounts regarding the 1690 event allowed us to estimate seismic parameters; a way to encourage new seismological research in the Amazon region. With this, the historical earthquake ceases to be almost a legend and instead gains importance in modern seismology. Reports of Father Betendorf, up to now unknown within the seismological community, were important to confirm the surprising effects on waters of the Amazon and Urubu rivers.

The existence of the earthquake of 1690 only came to light through a series of fortuitous events, a sickness, an arrest, a return, a field observation and all of these episodes are part of the Diary of Father Samuel Fritz. Brazilian seismology should pay a special tribute to this talented and charismatic religious man.

\section{ACKNOWLEDGMENTS}

I thank professors Marcelo Assumpção for his many constructive comments and Francisco Hilario Bezerra for his suggestions on the early version of the long gestation of this paper. I am indebted to Drs. Edgard Kausel and Leandro Rodrigues, for providing data of Chilean and Peruvian historic tremors and to Colonel Nilton Lampert, for obtaining from the Brazilian Army valuable support of my expedition through the left bank of the Amazon River in November 2010.

\section{RESUMO}

Combinando dados históricos com estudos sismológicos, trezentos anos de uma informação adormecida emergem como fonte do maior evento sísmico conhecido que atingiu o Brasil desde nossa colonização. O provável epicentro do tremor de 1690 foi na margem esquerda do Rio Amazonas, aproximadamente $45 \mathrm{~km}$ abaixo da hoje moderna Manaus. Um ano depois, quando passava pela área epicentral, um missionário encontrou testemunhas do tremor e observou marcantes modificações na topografia e na vegetação ao longo da margem do rio. Em 1692, outro padre confirmou a ocorrência do tremor e foi informado de que surgiram grandes ondas no rio que inundaram aldeias indígenas. A violência do terremoto espalhou ondas sísmicas pela floresta e balançou construções indígenas a mais de mil quilômetros de distância. O cálculo dos parâmetros sísmicos indicou uma magnitude estimada de 7, intensidade sísmica de IXMM e área de percepção de 2 milhões de $\mathrm{km}^{2}$. A descoberta 
de um terremoto deste tipo, caracterizado por longo período de recorrência, é de grande importância para estudos de sismicidade intraplaca. Para o Brasil ele desfaz o mito de que nosso país nunca foi afetado por terremotos severos.

Palavras-chave: terremoto da Amazônia, sismos históricos, sismicidade intraplaca, intensidade sísmica.

\section{REFERENCES}

ASSUMPÇÃO M. 2011. Terremotos e a convivência com as incertezas da natureza. RevistaUSP 91: 76-89.

AsSumpÇÃo M, ORTEGa R, BerRocal J AND Veloso JA. 1983. O sismo de Codajás-AM, de 05.08.1983. Rev Bras Geof 2: 39-44.

ASSUMPÇÃO M AND SACEK V. 2013. Intra-plate seismicity and flexural stresses in central Brazil. Geophys Res Lett 40: 487-491.

ASSUMPČ̃̃ M AND SUÁREZ G. 1988. Source mechanisms of moderate-size earthquakes and stress orientation in midplate. South Am Geophys Journal 92: 253-267.

ASSUMPÇÃO M AND VELOSO JAV. 1987. Levantamento de intensidade do sismo da Serra do Tombador, MT de 31.01.1955. Efeito no cálculo do risco sísmico no Mato Grosso. Relatório técnico do Convênio FUB/Eletronorte, $10 \mathrm{p}$.

BAKUN WH, JOHNSTON AC AND HOPPER MG. 2003. Estimating Locations and Magnitudes of Earthquakes in Eastern North America from Modified Mercalli Intensities. Bull Seism Soc Am 93: 190-202.

BALLORE FM. 1906. Lês tremblements de terre: géographie séismologique. Paris: Armand Colin, $475 \mathrm{p}$.

BERROCAL J, ASSUMPČ̃̃ M, ANTEZANA R, DiAs-NETO CM, ORTEGA R, Franca HE AND Veloso JAV. 1984 Sismicidade do Brasil, Instituto Astronômico e Geofísico, Universidade de São Paulo e Comissão Nacional de Energia Nuclear. São Paulo: Esperança, 320 p.

Betendorf JF. 1909. Chronica da Missão dos Padres da Companhia de Jesus no Estado do Maranhão. RIHGB, Tomo 72 Parte I, 697 p.

CERESIS. 1991. Catálogo de Intensidades y de Hipocentros, actualizados hasta el año de 1991. Pub. Centro Regional de Sismologia para América del Sur, Lima-Peru: CERESIS, $255 \mathrm{p}$.

DESLILE G. 2004. The mud volcanoes of Pakistan. Environ Geol 46: 1024-1029.

Domingo AP. 1939. El Terremoto del año 1687. R Arch Nac Perú XII: 1-6.

EIB - EARTHQUAKE INFORMATION BULLETIN MAY-JUNE. 1970 Earthquakes January-February 1970. Republic of the Philippines 2(3): 25.

EDMUNDSON G. 1922. Journal of the Travels and Labours of Father Samuel Fritz in the River of Amazons between 1686 and 1723, $2^{\text {nd }}$ ed., London: Hakluryt Society 51: 164.
Feng M, VAn Der Lee S AND Assumpcao M. 2007. Upper mantle structure of South America from joint inversion of waveforms and fundamental mode group velocities of Rayleigh waves. J Geophys Res 112: B04312, doi:10.1029/2006JB004449.

FRITZ S. 1880. Diario de la Bajada del Padre Samuel Fritz por el año de 1691. Cons. Ultramarino - Evora - 12: 128-200. IHGB, Microfilme, Pasta 271/279.

Gangopadhyay A AND TALWANI P. 2003. Symptomatic features of intraplate earthquakes. Seismol Res Lett 74: 863-883.

GARCIA R. 1912. O Diário do Padre Samuel Fritz. RIHGB 81: 353-397.

GRANA J AND RICHARDSON R. 1996. Tectonic stress within the New Madrid seismic zone. J Geophys Res 101: 54455458 .

HABERLEHNER H. 1978. Análise sismotectônica do Brasil, notas explicativas sobre o mapa sismotectônico do Brasil e regiões correlacionadas. An Cong Bras Geol Eng 2: 297-329.

INCE GC. 2011. The relationship between the performance of soil conditions and damage following an earthquake: a case study in Istambul, Turkey. Nat Haz Earth Syst Sci 11: $1745-1758$.

JOHNSTON AC. 1996. Seismic moment assessment of earthquakes in stable continental regions-I Instrumental seismicity. Geophys Journal Int 126: 314-344.

LA CONDAMINE JCM. 2010. Journal Du Voyage Fait Par ordre Du Roi A L'Equateur. Paris: Nabu Press, 686 p.

LA ESPADA DMJ. 1889. Noticias Auténticas del famoso rio Maranõn. Madrid: Fortanet, 676 p.

LINSER H. 1974. Interpretação das anomalias gravimétricas regionais na área Amazônica. Bol Tec Petrobras 1: 3-15.

LOCZY L. 1970. Role of transcurrent faulting in South American tectonic framework. AAPG Bulletin 54: 2111-2119.

MonTEIro MY. 1994. Fundação de Manaus. $4^{\text {th }}$ ed., Manaus: Metro Cubico, 159 p.

NUNN JA AND AIRES JR. 1988. Gravity Anomalies and Flexure of the Lithosphere at the Middle Amazon Basin, Brazil. J Geophys Res 93: 415-428.

NutTLi OW. 1973. The Mississippi Valley Earthquakes of 1811 and 1812: Intensities, Ground Motion and Magnitudes. Bull Seism Soc Am 63(1): 227-248.

OTAGO DAILY Times. MARCH 10, 2011. Steer clear of big trees in Christchurch: Civil Defense. http://www.odt.co.nz/ news/national/151189/steer-clear-big-trees-christchurchcivil defence. Last access on: July 05, 2013.

PINTO RF. 2006. O diário do Padre Samuel Fritz. Universidade Federal do Amazonas e Faculdade Salesiana Dom Bosco. EDUA/FSDB, Manaus, Amazonas, 272 p.

ReIs ACF. 1989. História do Amazonas. Belo Horizonte, MG: Itatiaia, $261 \mathrm{p}$.

REIS ACF. 1999. Manaus e outras vilas. Manaus: EDUA, 144 p.

RICHTER CF. 1958. Elementary Seismology. San Francisco and London: W H Freeman \& Co., 768 p.

Rodrigues HC. 1997. Diario del padre Fritz. $49^{\text {th }}$ Int Cong Americanists. Quito Ecuador, 154 p. 
SA NC. 2004. O campo de gravidade, o geóide e a estrutura crustal na América do Sul: Novas estratégias de representação. Tese de Livre-Docência, Universidade de São Paulo, 121 p.

SChulte SM AND MoOney WD. 2005. An updated global earthquake catalogue for stable continental regions: reassessing the correlation with ancient rifts. Geophys $\mathrm{J}$ Int 161: 707-721.

Servicio Sismológico de LA UniversidAd de ChILE. 2010. http://ssm.dgf.uchile.cl. Last access on: December 20, 2010.

STERNBERG HOR. 1950. Vales tectônicos na planície Amazônica? Rev Bras Geogr Ano XII, 4: 513-534.

STERNBERG HOR. 1953. Sismicidade e morfologia na Amazônia brasileira. An Acad Bras Cienc 25: 443-453.

STOVER CW AND COFFMAN JL. 1993. Seismicity of the United States, 1568-1989 (Revised). U.S. Geological Survey Professional Paper 1527, United States Government Printing Office, Washington.
THE FRITZ'S MAP OF 1691. O Rio Maranhão ou Rio Amazonas com a Missão da Companhia de Jesus. UNESCO Digital Library. http://www.wdl.org/pt/\#. Last access on: June $15,2013$.

Veloso JAV. 1996. A evolução do conhecimento sobre a sismicidade Amazônica. $1^{\circ}$ Workshop de Geofísica Aplicada ao Meio Ambiente. Belém, PA: SBGf 1: 3-6.

Veloso JAV. 1997. AmazonScope: a new BB seismic network for earthquake monitoring of Brazilian Amazon. In Abstracts 29th General Assembly IASPEI, Aug 18-28, Thessaloniki, Greece, $257 \mathrm{p}$.

Veloso JAV E Mendiguren JA. 1980. - Sismicidade da Amazônia e parte do Centro-Oeste Brasileiro. Simpósio Caract. Geolog. Geotectônicas da região Amazônica. ABGE, p. 43-57.

ZOBACK ML AND RICHARDSON RM. 1996. Stress perturbation associated with the Amazonas and other ancient continental rifts. J Geophys Res 101: 5459-5475. 